\title{
$\mathrm{CaO}-\mathrm{Al}_{2} \mathrm{O}_{3}-\mathrm{SO}_{3}$ 系仮焼粉末による 水溶液中のウランの回収
}

\author{
牧 俊 夫・*矢 野 正 行 \\ ( 京都大学 化学研究所) \\ * 現在 日本特殊触業 $)$
}

\begin{abstract}
硫酸アルミニウムと塩化アルミニウムの水溶液及び消石灰乳液を種々の割合に混合することによ って, 主にエットリンジャイト $\left(6 \mathrm{CaO} \cdot \mathrm{Al}_{2} \mathrm{O}_{3} \cdot 3 \mathrm{SO}_{3} \cdot 32 \mathrm{H}_{2} \mathrm{O}\right)$ からなる白色のケーキを作製した。

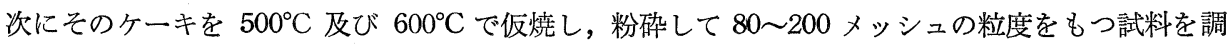
製した. $2.9 \mathrm{CaO} \cdot \mathrm{Al}_{2} \mathrm{O}_{3} 1 \cdot 4 \mathrm{SO}_{3}$ または $2.5 \mathrm{CaO} \cdot \mathrm{Al}_{2} \mathrm{O}_{3} \cdot 1.2 \mathrm{SO}_{3}$ の酸化物組成をもつ仮焼粉末は， 粒子強度とウランに対する捕集速度がかなり大きかった。すなおち U(VI) イオンの $100 \mathrm{ppm}$ を 主に $\left[\mathrm{UO}_{2}\left(\mathrm{CO}_{3}\right)_{3}\right]^{4-}$ の形で含むアルカリ水溶液の $50 \mathrm{ml}$ 中に，それらの粉末の $0.100 \mathrm{~g}$ を 2 時間 浸漬したとき，それらの試料は溶液中に存在する U(VI) イオンの 80 100\% を捕集した. 捕集し たウランは $60^{\circ} \mathrm{C}$ に保った $5 \% \mathrm{NaHCO}_{3}$ 溶液中に試料を 1 時間浸漬する方法で脱着させることが できる。

捕集前後の上記粉末のX線回折分析及び試料粉末を浸漬したときに起こる純水及び吸着液の $\mathrm{pH}$ の変化から, 本試料によるウランの捕集は, 試料の加水分解により生成する $\mathrm{Ca}(\mathrm{OH})_{2}$ と吸着液中 の $\left[\mathrm{UO}_{2}\left(\mathrm{CO}_{3}\right)_{3}\right]^{4-}$ イオンが反応して試料表面に二ウラン酸カルシウム $\left(\mathrm{CaU}_{2} \mathrm{O}_{7}\right)$ が生成するため に起こること，また脱着は $\mathrm{CaU}_{2} \mathrm{O}_{7}$ と上記 $\mathrm{NaHCO}_{3}$ 溶液が反応して U(VI) がもとの $\left[\mathrm{UO}_{2}\right.$ $\left.\left(\mathrm{CO}_{3}\right)_{3}\right]^{4-}$ イオンに戻るために起こることを明らかにした.

(1980 年 9 月 8 日受付)
\end{abstract}

\section{Recovery of Uranium from Aqueous Solutions Using Calcined Powders of $\mathrm{CaO}-\mathrm{Al}_{2} \mathrm{O}_{3}-\mathrm{SO}_{3}$ System}

\author{
Toshio MAKI and Masayuki YANO \\ (Institute for Chemical Research, Kyoto University)
}

Aqueous solutions of $\mathrm{Al}_{2}\left(\mathrm{SO}_{4}\right)_{3}(1.05 \mathrm{~g} / 100 \mathrm{ml}), \mathrm{AlCl}_{3}(0.82 \mathrm{~g} / 100 \mathrm{ml})$ and $\mathrm{Ca}(\mathrm{OH})_{2}$ slurry $(0.94 \mathrm{~g} / 50 \mathrm{ml})$ were mixed in various volume ratios and passed through a filter. White cakes left on the filter consisted mainly of ettringite $\left(6 \mathrm{CaO} \cdot \mathrm{Al}_{2} \mathrm{O}_{3} \cdot 3 \mathrm{SO}_{3} \cdot 32 \mathrm{H}_{2} \mathrm{O}\right)$. The cakes were then calcined at various temperatures of $300^{\circ} \sim 1000^{\circ} \mathrm{C}$ for 30 and $60 \mathrm{~min}$ and pulvelized to $80 \sim 200$ mesh powders.

The adsorption capacity of the powders for $\mathrm{U}(\mathrm{VI})$ ions dissolved in aqueous solutions was determined by immersing $0.100 \mathrm{~g}$ of their powders in $50 \mathrm{ml}$ of the aqueous solution containing $100 \mathrm{ppm}$ of $\mathrm{U}(\mathrm{VI})$ ions mainly in the form of $\left[\mathrm{UO}_{2}\left(\mathrm{CO}_{3}\right)_{3}\right]^{4-}$ for 2 hours. The amount of the $\mathrm{U}(\mathrm{VI})$. ions adsorbed by the powders was determined colorimetrically by extracting with the TBP solution the $\mathrm{U}(\mathrm{VI})$ ions left in the solution after adsorption.

The results obtained were summarized as follows.

1) Among the powders prepared, those of the oxide compositions, $2.9 \mathrm{CaO} \cdot \mathrm{Al}_{2} \mathrm{O}_{3} \cdot 1.4 \mathrm{SO}_{3}$ and $2.5 \mathrm{CaO} \cdot \mathrm{Al}_{2} \mathrm{O}_{3} \cdot 1.2 \mathrm{SO}_{3}$, all fired at $500^{\circ} \mathrm{C}$ or $600^{\circ} \mathrm{C}$ showed high adsorption capacity for $\mathrm{U}(\mathrm{VI})$ ions; the ratios of the amount of $\mathrm{U}(\mathrm{VI})$ ions adsorbed by the powders to that originally dissolved in the solution were $80 \sim 100 \%$, which were larger than for hydrous Ti(IV) oxide powders hitherto well known for their high adsorption capacity for U(VI) ions present in sea water.

2) X-ray diffraction analyses of the powders showed that small amount of II-CaSO 4 , $5 \mathrm{CaO} \cdot 3 \mathrm{Al}_{2} \mathrm{O}_{3}$ and $3 \mathrm{CaO} \cdot \mathrm{Al}_{2} \mathrm{O}_{3}$ crystals were present in the powders. The large parts of the powders, however, were considered to be dehydrated product of ettringite crystals in 
an amorphous state. Each grain of the powders was hard and kept its shape for a long time in water and alkaline solutions.

3) On the surface of powders immersed in the $U(V I)$ containing solution, a small amount of $\mathrm{CaU}_{2} \mathrm{O}_{7}$ crystals and a large amount of $\mathrm{CaCO}_{3}$ crystals were found to produce to form a yellow thin layer. The formation of this layer was caused probably by the reaction of $\mathrm{Ca}^{2+}$ ions dissolved from the powders with the $\left[\mathrm{UO}_{2}\left(\mathrm{CO}_{3}\right)_{3}\right]^{4-}$ ions present in solutions.

$7 \mathrm{Ca}(\mathrm{OH})_{2}+2 \mathrm{Na}_{4} \mathrm{UO}_{2}\left(\mathrm{CO}_{3}\right)_{8}=\mathrm{CaU}_{2} \mathrm{O}_{7}+6 \mathrm{CaCO}_{3}+8 \mathrm{NaOH}+3 \mathrm{H}_{2} \mathrm{O}$

4) The $\mathrm{CaU}_{2} \mathrm{O}_{7}$ crystals produced on the surface of the powders could be removed by immersing the powders in a $50 \mathrm{ml}$ of $5 \mathrm{wt} \% \mathrm{NaHCO}_{3}$ solution kept at $60^{\circ} \mathrm{C}$ for one hour. The ratios of desorption to adsorption were $70 \sim 80 \mathrm{wt} \%$.

$\mathrm{CaU}_{2} \mathrm{O}_{7}+8 \mathrm{NaHCO}_{3}=2 \mathrm{Na}_{4} \mathrm{UO}_{2}\left(\mathrm{CO}_{3}\right)_{3}+\mathrm{CaCO}_{3}+\mathrm{CO}_{2}+4 \mathrm{H}_{2} \mathrm{O}$

[Received September 8, 1980]

Key-words : Adsorption, Desorption, $\left[\mathrm{UO}_{2}\left(\mathrm{CO}_{3}\right)_{3}\right]^{4-}$ ion, Aqueous solution, $\mathrm{CaO}-\mathrm{Al}_{2} \mathrm{O}_{3}-\mathrm{SO}_{3}$ system

\section{1. 緒・言}

近年, 原子力エネルギーの利用が盛んになるに伴い， 種々の放射性物質を含む廃液の処理が重要になった ${ }^{11}$. 特に原子炉の中の核分裂生成物からウラン及びプルトニ ウムを分離し，これらを燃料として再使用する場 合に は, 分離操作の際に従来より多くの $U(V I)$ イオンが廃 液中に混入してくる恐れがあり, その適切な処理が望ま れる.一般に少量の放射性イオンを含む廃液を処理する には, 従来, アルカリ水溶液中で水酸化物とともに目的 イオンを凝集沈殿させるかイオン交換樹脂に吸着させる などの方法が用いられている2). しかし凝集沈殿法は水 酸化物沈殿が多量の水を含むため, その後の沪別処理な どの取り扱いが困難である。本研究で調製した材料は消 石灰にアルミナゲルを混合し，これを $5,600^{\circ} \mathrm{C}$ で焼成 したもので，その粒状試料は水中で崩壊せずに水溶液中 のウランを捕集することができるので取り扱いが便利で ある．また原料コストも低いので前記ウランを含む廃液 に浸漬して大部分のウランを回収し, 回收できなかった 微量のウランについては, シリカゲルなど無機の吸着剤 を用いて分離除去し ${ }^{3)}$, 廃液のウラン濃度を許容值以下 とするのが望ましいと考えられる.

一方,海水中に含まれる微量のウランを回収するには， 含水酸化チタンなどの吸着剤を用いるのが最も効果的と され, 近年多くの人によって海水ウラン回収のための吸 着剤の研究が行われるようになった ${ }^{4)}$. 含水酸化チタン に吸着したウランは普通, 重炭酸ソーダ $\left(\mathrm{NaHCO}_{3}\right)$ な どのアルカリ溶液で脱着する.この脱着液のウラン濃度 は $10 \sim 20 \mathrm{ppm}$ で, 最終的にウランのみを沈殿させるに は液を $0.5 \%$ 程度に濃縮する必要があるとされている ${ }^{5}$. 本研究で調製した試料は上記濃度の脱着液を 2 次的に濃 縮する材料として使用可能と考えられる.

本研究で調製した試料はアルカリ液中に $\left[\mathrm{UO}_{2}\left(\mathrm{CO}_{3}\right)_{3}\right]^{4-}$ イオンの形で含まれるウランを回収する場合に特に有効 であり，その使用範囲は限られるが，捕集速度が大きい ので本研究ではその調製法と吸着機構について 報告す る.

\section{2. 実 験 方 法}

\section{1 吸着試料の調製法亡分析法 (化学分析, $\mathrm{X}$ 線分 析}

カルシウムを含む化合物粉末の U(VI) イオン吸着量 を調べた結果, 消石灰 $\left(\mathrm{Ca}(\mathrm{OH})_{2}\right)$ 粉末のみ大きい吸着 率を示したが，U(VI) イオンを吸着した $\mathrm{Ca}(\mathrm{OH})_{2}$ 粉 末は水中に分散し，これを単独で吸着剤として使用する ことは不可能である (表 3 参照).そこで消石灰乳液にア ルミナゲルをあらかじめ生成させたアルミニウム塩の水 溶液を添加混合する以下の方法で，水中で分散崩壊しな い吸着試料を調製しようとした。

\subsection{1 $\mathrm{CaO}-\mathrm{Al}_{2} \mathrm{O}_{3}-\mathrm{SO}_{3}$ 系試料}

まず $\mathrm{CaO}$ と $\mathrm{Al}_{2} \mathrm{O}_{3}$ 成分の割合を $80: 20(\mathrm{~mol})$ と し, $\mathrm{Al}_{2} \mathrm{O}_{3}$ の出発原料として硫酸アルミニウム $\left(\mathrm{Al}_{2}\right.$ $\left(\mathrm{SO}_{4}\right)_{8} \cdot 18 \mathrm{H}_{2} \mathrm{O}$, 特級試薬) 及び塩化アルミニウム $\left(\mathrm{AlCl}_{3}\right.$. $6 \mathrm{H}_{2} \mathrm{O}$ ，特級試薬）を使用し，これらの水溶液と消石灰 乳液とを混合した。すなわち $\mathrm{Al}_{2}\left(\mathrm{SO}_{4}\right)_{3} \cdot 18 \mathrm{H}_{2} \mathrm{O}$ 粉末 $2.06 \mathrm{~g}$ を水 $100 \mathrm{ml}$ に溶解したもの, $\mathrm{AlCl}_{3} \cdot 6 \mathrm{H}_{2} \mathrm{O}$ 粉末 $1.48 \mathrm{~g}$ を水 $100 \mathrm{ml}$ に溶解したもの及び消石灰乳液を表 1 に示寸種々の容積比に混合して使用した。ただし消石 灰乳液は $\mathrm{Ca}(\mathrm{OH})_{2}$ 粉末（純度 $96 \%$,メルク社製試薬, 粒度は平均 $1 \mu$ であるがこれより大きい粒子もかなり含

Table 1. Mixing volume ratios of solutions and slurry used for preparation of adsorbents.

\begin{tabular}{|c|c|c|c|}
\hline \multirow{2}{*}{ Sample } & \multicolumn{3}{|c|}{ Solution \& slurry (m 1$)$} \\
\hline & ${ }^{*} \mathrm{AI}_{2}\left(\mathrm{SO}_{4}\right)_{3}{ }^{*} \mathrm{AlCl}_{3}$ & $\begin{array}{l}\mathrm{Ca}(\mathrm{OH}) \\
\text { slurry }\end{array}$ & Total \\
\hline A & 100 & 50 & 150 \\
\hline B & 25 & 50 & 150 \\
\hline$c$ & 50 & 50 & 150 \\
\hline D & 100 & 50 & 150 \\
\hline $\begin{array}{rl}* & 2.06 \mathrm{~g} \\
& \text { were } \\
& \text { ively. }\end{array}$ & $\begin{array}{l}\mathrm{Al}_{2}\left(\mathrm{SO}_{4}\right)_{3} \cdot \dot{3}_{2} \mathrm{H}_{2} \mathrm{O} \\
\text { ssolved in } 100 \mathrm{mI}\end{array}$ & $\begin{array}{l}1.48 \mathrm{~g} \text { of } \\
\text { pure wate }\end{array}$ & $\begin{array}{l}\mathrm{AlCl}_{3} \cdot 5 \mathrm{H} \\
\text { respec } \\
\quad\end{array}$ \\
\hline
\end{tabular}


まれる) $0.94 \mathrm{~g}$ を水 $50 \mathrm{ml}$ に入れ, あらかじめ 30 分 かく拌したものを使用した. 表 1 の試料 D注試料 A, B 及びCの比較試料である. アルミニウム塩の単独及び混 合液は消石灰乳液と混合する前にあらかじめ $\mathrm{NH}_{4} \mathrm{OH}$ (1:1) を液の $\mathrm{pH}$ が 8.0 になるまで添加し, 加熱煮 沸してアルミナゲルを生成させた. これは $\mathrm{Al}_{2} \mathrm{O}_{8}$ 成分 が他の成分より過剩となっても試料中にアルミナゲルと して残り, 試料の粒子強度を大きくするのに役立つと考 えたためである.アルミニウム塩溶液と消石灰乳液の混 合液は 30 分かく拌し, 沈殿物を少量の水で洗浄しなが ら吸引沪過した. 使用した水の量は全部で約 $150 \mathrm{ml}$ で あるが，ビーカーに付着したアルミナゲルを消石灰乳液 に移す場合には, かなりの水を必要とし, 混合液の全容 量は約 $200 \mathrm{ml}$ である. 生成した沈殿物は室温で乾燥後 $300^{\circ} \sim 1000^{\circ} \mathrm{C}$ で 30 分焼成し; 粉砕して 80 200メッ シュの粒度をもつ試料とした。

\subsection{2 $\mathrm{SO}_{3}$ を含まない試料}

前記 $\mathrm{SO}_{3}$ 成分を含まない試料 $\mathrm{D}$ のほかに, $\mathrm{SO}_{3}$ を含 む試料 $\mathrm{A}, \mathrm{B}$ 及び Cを仮焼したときに， $600^{\circ} \mathrm{C}$ 以上で 生成する $5 \mathrm{CaO} \cdot 3 \mathrm{Al}_{2} \mathrm{O}_{3}\left(\mathrm{C}_{5} \mathrm{~A}_{3}\right)$ 及び $3 \mathrm{CaO} \cdot \mathrm{Al}_{2} \mathrm{O}_{3}\left(\mathrm{C}_{3} \mathrm{~A}\right)$ 結晶を合成した. $\mathrm{C}_{3} \mathrm{~A}$ 到 $\mathrm{CaCO}_{3}$ と $\mathrm{Al}_{2} \mathrm{O}_{3}$ の $\mathrm{C}_{3} \mathrm{~A}$ に 相当する混合粉末を $1400^{\circ} \mathrm{C} 2$ 時間仮焼することによ り, $\mathrm{C}_{5} \mathrm{~A}_{3}$ は $\mathrm{C}_{5} \mathrm{~A}_{3}$ に相当する同し原料の混合粉末を $1400^{\circ} \mathrm{C} 3$ 時間仮焼することにより調製した。

\subsection{3 その他の試料}

表 1 に示す $\mathrm{A}, \mathrm{B} 及 ひ ゙ \mathrm{C}$ 試料と吸着能及び吸着機構を 比較するため, $\mathrm{CaO}$ と $\mathrm{Al}_{2} \mathrm{O}_{3}$ を主成分とする市販アル ミナセメント（構成結晶, $\mathrm{CaO} \cdot \mathrm{Al}_{2} \mathrm{O}_{3}, 3 \mathrm{CaO} \cdot \mathrm{Al}_{2} \mathrm{O}_{3}$ な ど）及び $\mathrm{CaO}, \mathrm{Al}_{2} \mathrm{O}_{3}$ 及び $\mathrm{SiO}_{2}$ を主成分とする市販 ポルトランドセメントの微粉末並びにこれらの微粉末に 水を加えて凝固させた後, 粉砕して 80 200 メッシュ の粒度としたものを使用した. また吸着能の比較試料と して緒言で述べた含水酸化チタン粉末を用いた. その調 製方法は次のとおりである ${ }^{6)}$. すなわち硫酸第二チタン $\left(\mathrm{Ti}\left(\mathrm{SO}_{4}\right)_{2} \cdot 10 \mathrm{H}_{2} \mathrm{O}, 1\right.$ 級試薬) $5.0 \mathrm{~g}$ を水 $300 \mathrm{ml}$ に溶 解し, 30 分間かく拌して半透明になった液に $\mathrm{NH}_{4} \mathrm{OH}$ (1:1) を液の $\mathrm{pH}$ が 8.0 になるまで加えて 室温で沈 殿を生成させた. 次にこの沈殿に付着しているアンモニ アがほとんどなくなるまで水洗, 濾過後, 沈殿物を 3 日 間室内で乾燥した，吸着試料としては，これを粉砕して 粒度が 80〜200メッシュのもののみを取り, 更にこれ を $50^{\circ} \mathrm{C}$ で 1 時間乾燥乙たものを用い゙た。

\subsection{4 化学分析}

$500^{\circ} \mathrm{C}$ で焼成した吸着試料の微粉末 $0.100 \mathrm{~g}$ をビ一カ 一にとり, 濃塩酸を少量入れ加熱溶解した後液を 2 分し, 一方の液で硫酸バリウム法により $\mathrm{SO}_{3}$ を, 他方の液で $\mathrm{Al}_{2} \mathrm{O}_{3}$ をを重量法により定量した. $\mathrm{Al}_{2} \mathrm{O}_{3}$ を水酸化アルミ ニウムとして沪別したあとの液を用いてキレート法で
Ca の分析を行った. なお試料調製の際の沈殿物の構成 成分を知るために，上記と同じ方法で沈殿物を取ったあ との沪液の化学分析を行った.

\subsubsection{X 線回析分析}

焼成温度の増大による試料の構成結晶種の変化, 吸着 液及び純水に浸漬した場合に起こる試料表面の変化を知 るためほほとんどの試料についてX線回折を行った。 ま た吸着後の試料表面に生成していると思われるウラン化 合物の有無と種類を明らかにするため, 試料微粉末 0.5 $\sim 1.0 \mathrm{~g}$ を内径 $15 \mathrm{~mm}$, 幅 $5 \mathrm{~mm}$, 厚さ $1 \mathrm{~mm}$ のアル ミニウム製リング内に入れ，4〜5 トンでプレスしたも のを作製し，されをウラン原液又は吸着液に 24 時間浸 漬した後その表面のX線回折を行い，微量のウラン化合 物でも検出できるようにした.

\section{2 ウラン含有液の調製}

\subsection{1 ウラン原液}

ウラン含有試薬として入手しやすい酢酸ウラン $\left[\left(\mathrm{CH}_{3}\right.\right.$ $\mathrm{COO})_{2} \cdot \mathrm{UO}_{2} \cdot 2 \mathrm{H}_{2} \mathrm{O}$, メルク社製試薬，純度 $99 \%$ 以上) の $1.782 \mathrm{~g}$ を水 $200 \mathrm{ml}$ に溶解し，アンモニアを加えて ウラン酸アンモン $\left[\left(\mathrm{NH}_{4}\right)_{2} \mathrm{U}_{2} \mathrm{O}_{7}\right]$ の黄色沈殿を生成さ せた，次いでこれを塩酸に溶解し， $\mathrm{CH}_{3} \mathrm{COO}^{-}$イオンを 分解するためいったん蒸発乾固した後, 水で溶解したも のを $500 \mathrm{ml}$ メスフラスコに入れ，募沸して炭酸ガスを 追い出した水で薄め，U(VI) $2000 \mathrm{ppm}$ の溶液を調製し た。これをウラン原液として保存し，実験の都度この液 の一定量をとり多くの場合希釈して使用した。

\subsection{2 ウラン吸着夜}

一定量のウラン原液を水で 20 倍に薄め $U(V I) 100$ ppm の液を作製して吸着試験に使用した。この吸着液 中の $\mathrm{U}(\mathrm{VI})$ の量は, 種々の量の酸化ウラン粉末 $\left(\mathrm{UO}_{2}\right.$, 純度ほとんど 100\%) の塩酸溶解液を用いて液の吸光度 とウラン量の関係を示す検量線をあらかじめ作成してお き，これを用いて検定した．上記吸着液の濃度はほとん ど $100 \mathrm{ppm}$ で，これより濃度が高い場合には水で希釈 し正確に $100 \mathrm{ppm}$ として使用した。また吸着液中に含 まれる U(VI) イオンがすべて $\left[\mathrm{UO}_{2}\left(\mathrm{CO}_{3}\right)_{3}\right]^{4-}$ イオン となるように液の $\mathrm{CO}_{3} / \mathrm{U}$ 比が 10 となるまで無水炭酸 ソーダの粉末を加えた．ただしこの液の $\mathrm{pH}$ は 10 を越 え高すぎるので少量の希塩酸を加え $\mathrm{pH}$ を 8.0 に調節 した液を使用した。試料をこの液に浸漬したときその表 面に吸着する U(VI) は微量でX線回折で検出できない ので，この目的の場合にはウラン原液をそのまま吸着液 として用いた。ただし上記希釈液の場合と同様，炭酸ソ 一ダ粉末と希塩酸で液の $\mathrm{pH}$ を 8.0 に調節した。

次に上記錯イオンの安定度定数 ${ }^{7)}$ は大きいが $\mathrm{pH} 8.0$ の吸着液中の $\mathrm{U}(\mathrm{VI})$ がすべて $\left[\mathrm{UO}_{2}\left(\mathrm{CO}_{3}\right)_{3}\right]^{4-}$ の形で 含をれているかどらかを確かめるため, 分光光度計を用 いて紫外部の吸収スペクトルを測定した．また同じ目的 
でウラン原液に $\mathrm{CO}_{3} / \mathrm{U}=10$ まで炭酸ソーダを加えた液, 及び炭酸ソーダと塩酸で $\mathrm{pH}$ を 8.0 とした液を約 20 倍に濃縮し，その 2,3 滴を 2 枚の $\mathrm{KRS}$ 板 ( $コ$ ウ化夕 リウムと臭化タリウムの固溶体の板）の間に入れ，郝外 分光光度計（日立製作所製 EPI-S 2 型）を用いてその スペクトルを測定した。

\section{3 吸脱着実験}

\subsection{1 吸着量と脱着量の測定}

吸着試験は粒度 80 ～200 メッシュの試料 $0.100 \mathrm{~g}$ を $100 \mathrm{ml}$ 三角フラスコに入れ，これに $100 \mathrm{ppm}$ の U(VI) を含む上記吸着液 $50 \mathrm{ml}$ を入れて振とう機にかけて行っ た. 吸着時間は 2 時間とし， 2 時間経過する 10 分前に 振とうを中止し，フラスコを静止させ 10 分後に上澄み 液の $10 \mathrm{ml}$ を採取した。振とうを止めた後液が濁って いる場合には，遠心分離機にかけて透明な液とし同じく $10 \mathrm{ml}$ を採取した. 採取液に硝酸ソーダを加え $\mathrm{pH}$ を 3.0 とした後, 容量 $50 \mathrm{ml}$ の分液漏斗に同じ容量の抽 出液（TBP $25 \%$ とイソオクタン $75 \%$ 容量の混合液） とともに入れ室温で 2 時間振とうさせた ${ }^{8)}$ ．次いで分離 した抽出液の紫外部 $235 \mathrm{~m} \mu$ の吸光度を測定し，あらか じめ作製した検量線により残留液中のウラン量を決定し た. 試料の $U(V I)$ 吸着量は出発液の $U(V I)$ 量から残 留液中の $U(V I)$ 量を差し引きこれを吸着率で表した。

吸着後の残留液を除き, 三角フラスコに純水を入れて 試料を 2 回洗浄し, 次いで脱着液の $50 \mathrm{ml}$ を入れ, 容器 をときどき振とうして $60 \pm 2^{\circ} \mathrm{C}$ の恒温槽中に 1 時間保持 した．室温まで泠却した後上澄み液中の U(VI) 量を同 じ方法で定量しここの值を吸着量で除したものを脱着率 とした. 更に脱着後の試料について同じ方法で 2 回目の 吸着率を測定した．なお脱着液としては重炭酸ソーダの $5 \%$ 溶液を使用する場合が結果がよく，脱着率の值はす べてこの液を使用したときの值である.

\subsection{2 pH 測定}

吸着による液の $\mathrm{pH}$ の変化を知るためすべての試料に ついて吸着後の残留液の $\mathrm{pH}$ を測定した。 また吸着機構 を調べるため代表的な試料について，試料浸漬後 2 時 間，吸着液の $\mathrm{pH}$ を連続測定した．同時に試料を純水に 浸漬したときの $\mathrm{pH}$ の変化も測定した。

\section{3. 実 験 結 果}

\section{1 室温で乾燥した沈殿物の構成結晶}

試料 $\mathrm{A} ， \mathrm{~B}$ 及びCには液量に関倸なくすべてエットリ ンジャイト (ettringite, $3 \mathrm{CaO} \cdot \mathrm{Al}_{2} \mathrm{O}_{8} \cdot \mathrm{CaSO}_{4} \cdot 32 \mathrm{H}_{2} \mathrm{O}$, 文献9)及び ASTM card 9-414）が認められた。混合液 の量が少ない場合 $(150 \mathrm{ml})$ には，多い場合 $(200 \mathrm{ml})$ に 比べエットリンジャイト（E 結晶と略す）の X 線回折 強度が大きく, 硫酸カルシウム二水塩 $\left(\mathrm{CaSO}_{4} \cdot 2 \mathrm{H}_{2} \mathrm{O}\right)$ の小さいピークも認められた。 また $\mathrm{E}$ 結晶の回折強度
は $\mathrm{A} \rightarrow \mathrm{B} \rightarrow \mathrm{C}$ の順に小さくなった. これに対し混合液の 量が多い場合には，いずれも $\mathrm{CaSO}_{4} \cdot 2 \mathrm{H}_{2} \mathrm{O}$ は認められ ず, $\mathrm{E}$ 結晶の回折強度も液量の少ない場合より小さかっ たが，試料による違いはほとんど認められなかった。 $\mathrm{AlCl}_{3}$ を用いて調製した試料 $\mathrm{D}$ には, calcium aluminate chloride hydrate $\left(3 \mathrm{CaO} \cdot \mathrm{Al}_{2} \mathrm{O}_{3} \cdot \mathrm{CaCl}_{2} \cdot 10 \mathrm{H}_{2} \mathrm{O}\right.$, 文献帛), $\alpha$-form, ASTM card 19-202) と calcite $\left(\mathrm{CaCO}_{8}\right)$ が かなり認められた。 しかし $\mathrm{CaCl}_{2}$ を含む結晶の回折強 度は, 前記 $\mathrm{E}$ 結晶のそれより全体に小さく，沈殿物に 入らず汇液に逃げる $\mathrm{Ca}$ 成分も試料 $\mathrm{A} ， \mathrm{~B}$ の場合よりか なり多かった。

\section{$3.2500^{\circ} \mathrm{C}$ 仮焼試料の化学分析}

試料調製の際の混合液の量を $150 \mathrm{ml}$ とするか $200 \mathrm{ml}$ にするかで得られる沈殿物の成分は厳密には異なる。し かしX線回折図はいずれの場合も主に E 結晶の存在を示 しており，また仮燒試料の水溶液中ウランに対する吸着 能も両者で大きい差はなかった。むしろ試料の粒子強度 は混合液の量が $200 \mathrm{ml}$ の場合の方が大きかった。した がってこの試料 (ただし $500^{\circ} \mathrm{C}, 30$ 分仮焼) について分 析した結果を表 2 に示す．表中の加熱減量を除くと初め の 3 成分または 2 成分のモル組成は試料 $\mathrm{A}, 2.9 \mathrm{CaO}$. $\mathrm{Al}_{2} \mathrm{O}_{3} \cdot 1.4 \mathrm{SO}_{8}$; 試料 $\mathrm{B}, 2.9 \mathrm{CaO} \cdot \mathrm{Al}_{2} \mathrm{O}_{3} \cdot 1.4 \mathrm{SO}_{3}$; 試料 $\mathrm{C}, 2.5 \mathrm{CaO} \cdot \mathrm{Al}_{2} \mathrm{O}_{3} \cdot 1.2 \mathrm{SO}_{8}$ 及び試料 $\mathrm{D}, 0.9 \mathrm{CaO} \cdot \mathrm{Al}_{2} \mathrm{O}_{3}$ である.

\section{3 仮焼温度之構成結晶の関係}

試料 C を 500,600 及び $1000^{\circ} \mathrm{C}$ で 30 分仮焼した 粉末の X 線回折の結果を図 1 亿示す（a) は室温で乾 燥した沈殿物の $\mathrm{E}$ 結晶の回折ピークである．仮焼温度 が $100^{\circ} \mathrm{C}$ を越えると回折ピークはすべていったん消失 する. $500^{\circ} \mathrm{C}$ で仮焼時間を 30 分から 60 分にすると $600^{\circ} \mathrm{C}$ の場合と同じ結果が得られた。また $600^{\circ} \mathrm{C}$ で 60 分仮焼すると $1000^{\circ} \mathrm{C}$ で回折ピークが大きくなる $\mathrm{C}_{5} \mathrm{~A}_{8}$ と $\mathrm{C}_{3} \mathrm{~A}$ 結晶むわずかに認められた. 試料 $\mathrm{D}$ も仮焼温度 が $100^{\circ} \mathrm{C}$ を越えると室温で生成した $3 \mathrm{CaO} \cdot \mathrm{Al}_{2} \mathrm{O}_{3} \cdot \mathrm{CaCl}_{2}$ $\cdot 10 \mathrm{H}_{2} \mathrm{O}$ 結晶の回折ピークは消失し, $500^{\circ} \mathrm{C}$ と $600^{\circ} \mathrm{C}$ で

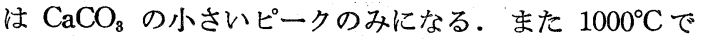
は $\mathrm{C}_{5} \mathrm{~A}_{3}$ と $\mathrm{C}_{3} \mathrm{~A}$ の大きい回折ピークのみ現れる.

\section{4 ウラン含有液}

Table 2. Chemical analyses of powders calcined at $500^{\circ} \mathrm{C}$ for $30 \mathrm{~min}$.

\begin{tabular}{ccccccc}
\hline \multirow{2}{*}{ Sample } & \multicolumn{5}{c}{ Composition(wt\%) } \\
\cline { 2 - 7 } & $\mathrm{CaO}$ & $\mathrm{Al}_{2} \mathrm{O}_{3}$ & $\mathrm{SO}_{3}$ & * Ig.loss & Total \\
\hline A & 38.6 & 24.0 & 25.6 & 9.5 & 97.7 \\
B & 38.8 & 24.0 & 27.4 & 10.0 & 100.2 \\
C & 36.9 & 26.4 & 24.5 & 11.3 & 99.1 \\
D. & 26.7 & 52.8 & $-\ldots$ & 22.0 & 101.5 \\
\hline * & Weight loss of sample powders heated until \\
1000 C & & & & &
\end{tabular}




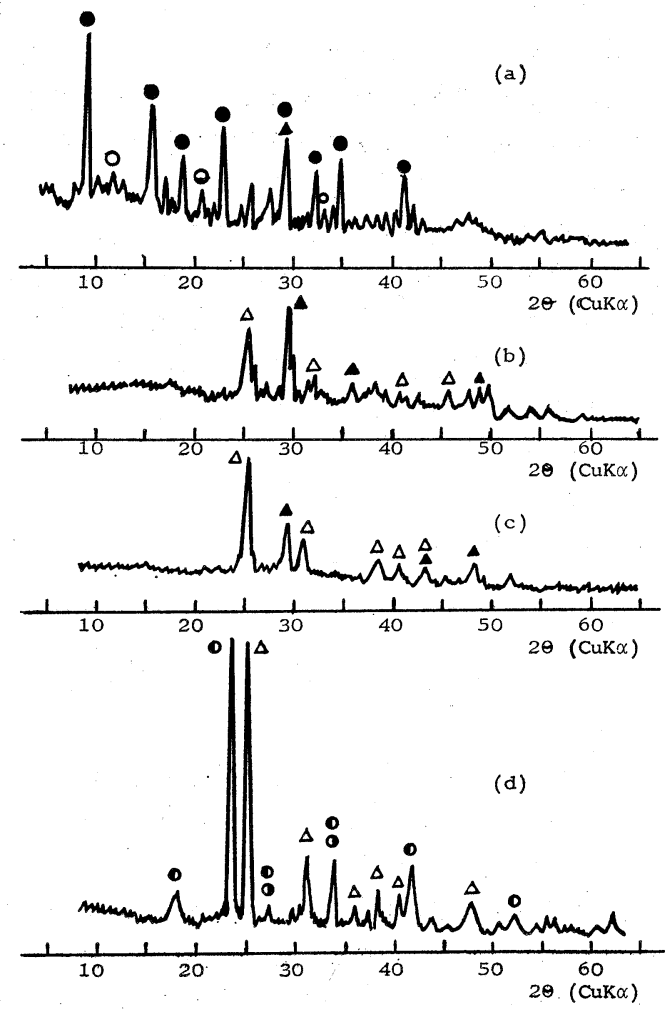

Fig. 1. Changes in X-ray powder diffraction patterns of calcined materials having $2.5 \mathrm{CaO}$. $\mathrm{Al}_{2} \mathrm{O}_{3} \cdot 1.2 \mathrm{SO}_{3}$ composition with increasing temperature.

(a) : Precipitate dried at room temperature for 3 days

(b) : Calcined at $500^{\circ} \mathrm{C}$ for $30 \mathrm{~min}$.

(c) : Calcined at $600^{\circ} \mathrm{C}$ for $30 \mathrm{~min}$.

(d) : Calcined at $1000^{\circ} \mathrm{C}$ for $30 \mathrm{~min}$.

: $6 \mathrm{CaO} \cdot \mathrm{AlO}_{3} \cdot 3 \mathrm{SO}_{3} \cdot 32 \mathrm{H}_{2} \mathrm{O}, \boldsymbol{\Delta}: \mathrm{CaCO}_{3}$ (calcite),

$\triangle:$ II $-\mathrm{CaSO}_{4}, \mathrm{O}: 5 \mathrm{CaO} \cdot 3 \mathrm{Al}_{2} \mathrm{O}_{3}, \mathrm{O}: 3 \mathrm{CaO} \cdot \mathrm{Al}_{2} \mathrm{O}_{3}$.

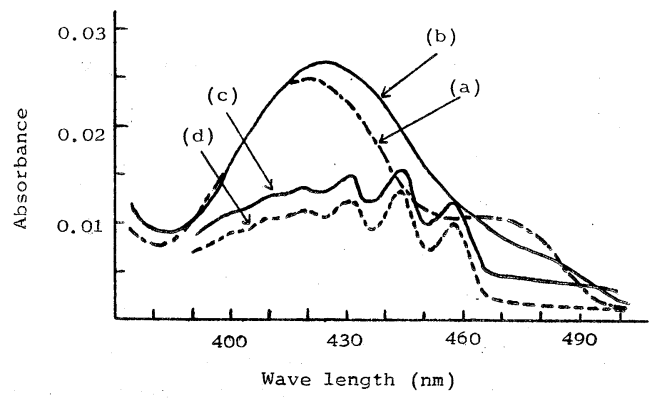

Fig. 2. Absorption spectra of aqueous solutions containing $100 \mathrm{ppm}$ of $\mathrm{U}(\mathrm{VI})$ ions.

(a) : $\mathrm{CO}_{3} / \mathrm{U}=0 \mathrm{NaOH}$ powders were added to initial solution ( $\mathrm{pH} 8.0$ )

(b) : $\mathrm{CO}_{3} / \mathrm{U}=2(\mathrm{pH} 8.0)$

(c) : $\mathrm{CO}_{3} / \mathrm{U}=5 \sim 25(\mathrm{pH} 10.4 \sim 11.0)$

(d) : Decreased until $\mathrm{pH} 8.0$ by adding dilute

$\mathrm{HC} 1$ to the solution of $\mathrm{CO}_{3} / \mathrm{U}=10$
図 2 (d) にウラン吸着液 ( $\mathrm{pH} 8.0$ ), 図 2 (c) に $\mathrm{CO}_{8} / \mathrm{U}$ の比が 10 で希塩酸を加える前の $\mathrm{pH}$ が 10.5 の液の紫 外部吸収スペクトル測定結果を示す. 図中の (a) と (b) 曲線は U(VI) 100 ppm の液 ( $\mathrm{pH}$ 約 4.0) に $\mathrm{NaOH}$ 及び $\mathrm{Na}_{2} \mathrm{CO}_{3}$ を $\mathrm{pH} 8.0$ まで加えた液についての結果 を示したもので同じ $\mathrm{pH} 8.0$ でも吸収スペクトルにかな り差のあることが分る. 図 3 はウラン原液を濃縮した液 の赤外吸収スペクトル測定結果で, 点線で示す曲線が $\mathrm{CO}_{3} / \mathrm{U}=10, \mathrm{pH} 10.5$ の液に希塩酸を加え $\mathrm{pH} 8.0$ と した後濃縮した液, 実線で示す曲線が希塩酸を加えずに pH 10.5 のまま濃縮した液についての結果を示す.

\section{5 カルジウム化合物粉末のウラン吸着}

$\mathrm{Ca}(\mathrm{OH})_{2}, \mathrm{II}-\mathrm{CaSO}_{4}$ 及び $\mathrm{CaCO}_{3}$ 微粉末のウラン吸 着率測定結果を表 3 に示す. 吸着後の残留液を遠心分離 後測定した值で比較すると， II- $\mathrm{CaSO}_{4}$ と $\mathrm{CaCO}_{3}$ は全 く吸着が起こらないが, $\mathrm{Ca}(\mathrm{OH})_{2}$ は $100 \%$ に近い吸着 率を示し，比較のために測定した含水酸化チタンより大 きい值をもつことが分る.

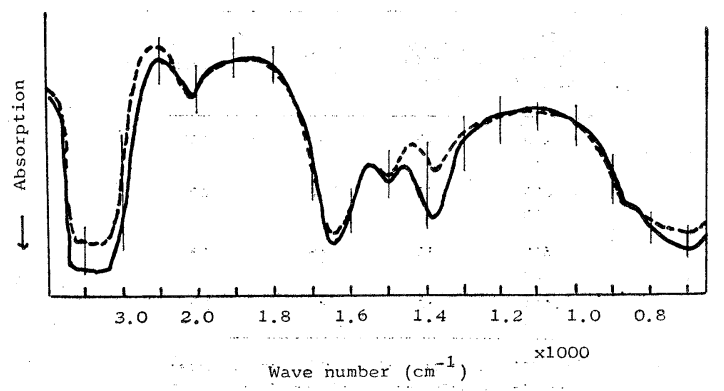

Fig. 3. IR spectra of solutions containing $\left[\mathrm{UO}_{2}\left(\mathrm{CO}_{3}\right)_{3}\right]^{4-}$ ions.

— : $\mathrm{CO}_{3} / \mathrm{U}=10(\mathrm{pH} 10.5)$

... : Decreased until $\mathrm{pH} 8.0$ by adding dilute $\mathrm{HCl}$ to the solution of $\mathrm{CO}_{3} / \mathrm{U}=10$

Table 3. Uptake of $U(V I)$ ions in aqueous solutions by calcium compounds and state of residual solutions after adsorption.

\begin{tabular}{cccl}
\hline Matexials & $\begin{array}{c}* \text { ** Uptake } \\
(\%)\end{array}$ & $\mathrm{pH}$ & $\begin{array}{l}\text { State of } \\
\text { solution }\end{array}$ \\
\hline $\mathrm{Ca}(\mathrm{OH})_{2}$ & $37.0(94.0)$ & 12.0 & $\begin{array}{l}\text { Turbid \& } \\
\text { yellow }\end{array}$ \\
${ }^{*} \mathrm{CaSO}_{4}$ & $\ldots-(0)$ & 7.5 & $\begin{array}{l}\text { Turbid \& } \\
\text { white }\end{array}$ \\
${ }^{*} \mathrm{CaCO}_{3}$ & $0(0)$ & 8.7 & $\begin{array}{l}\text { Turbid \& } \\
\text { white }\end{array}$ \\
$\mathrm{IiO}(\mathrm{OH})_{2}$ & $39.0(40.0)$ & 7.8 & Clear \\
\hline
\end{tabular}

* : Fine powders of commercial reagent were used.

* $: 0.100 \mathrm{~g}$ of powders was immersed in $50 \mathrm{mI}$ of solution containing 100ppm of $U(V I)$ ions for 2 hours. Uptake were calculated from analytical values of $\mathrm{U}(\mathrm{VI})$ ions remaining in solutions after adsorption. The values in parentheses were obtained for the residual solutions clarified with the centrifuge.

.-.: unable to measure because of high turbidity of solution 


\section{$3.6 \mathrm{SO}_{3}$ を含む焼成試料の吸脱着}

表 4 に試料 C (粒度 80 200 メッシュ) の吸脱着率 測定結果を示す．試料を浸漬したときの吸着液の濁度は $\mathrm{Ca}(\mathrm{OH})_{2}$ 微粉末のみの場合よりはるかに小さくなり， 残留液を遠心分離にかけてもかけなくても吸着率の值に ほとんど差が認められなくなった，表 4 より $500^{\circ} \mathrm{C} ゃ$ $600^{\circ} \mathrm{C}$ の低温で焼成した試料の吸着率が最も大きく，含 水酸化チタン（粒度 80〜200メッシュ）の值（表 3 ）よ りかなり大きいことが分る．またこれらの試料の脱着率 約 $70 \%$ は含水酸化チタンの值と同程度であった. しか し 2 回目の吸着率はいずれも小さく, 吸着能が著しく低 下していることが分る。

\section{7 試料浸漬後の純水及び吸着液の $\mathrm{pH}$ の変化} 図 4 に $500^{\circ} \mathrm{C} ， 30$ 分焼成した試料 $\mathrm{C}$ を純水及びウラ

Table 4. Adsorption and desorption of $\mathrm{U}(\mathrm{VI})$ ions by the powders of $2.5 \mathrm{CaO}$. $\mathrm{Al}_{2} \mathrm{O}_{3} \cdot 1.2 \mathrm{SO}_{3}$ composition calcined at various temperatures.

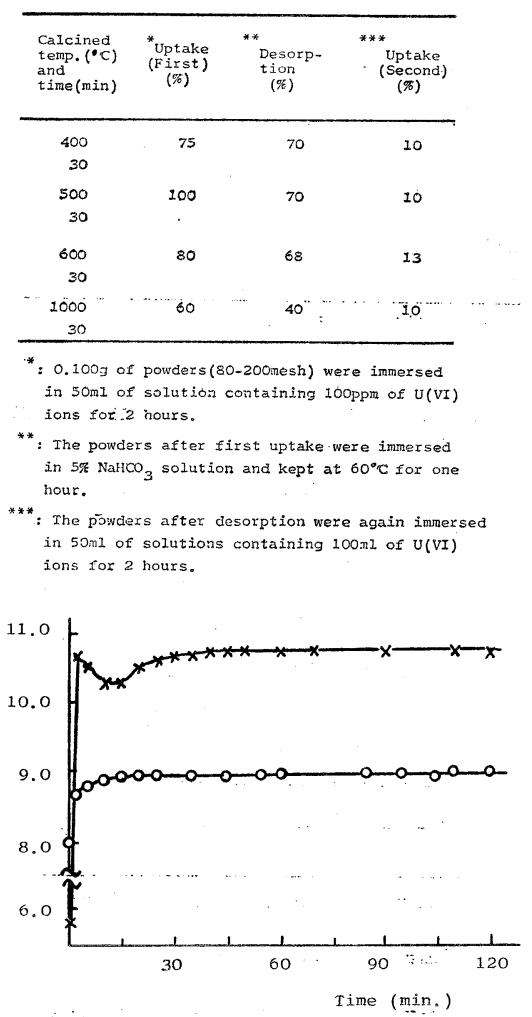

Fig. 4. Changes in $\mathrm{pH}$ of pure water and $\mathrm{U}(\mathrm{VI})$ containing solution caused by immersion of calcined powders of $2.5 \mathrm{CaO} \cdot \mathrm{Al}_{2} \mathrm{O}_{3} \cdot 1.2 \mathrm{SO}_{3}$ composition.

$-x-: 0.100 \mathrm{~g}$ of powders calcined at $500^{\circ} \mathrm{C}$ was immersed in $50 \mathrm{ml}$ of pure water.

$-\mathrm{O}-: 0.100 \mathrm{~g}$ of powders calcined at $500^{\circ} \mathrm{C}$ was immersed in $50 \mathrm{ml}$ of solution containing $100 \mathrm{ppm}$ of $\mathrm{U}(\mathrm{VI})$ ions.
ン吸着液に浸漬し液の $\mathrm{pH}$ を測定した結果を示す. 図よ り純水に浸漬したときは $\mathrm{pH}$ が直ちに 10 11 の值を示 すこと，吸着液に浸漬したときは直ちに 9 付近の值を示 すこと及びそれらの值は 2 時間後も変らないことが分 る.

\section{8 プレスした試料の吸着後の表面の $\mathrm{X}$ 線回折}

$600^{\circ} \mathrm{C}$ で焼成した試料 B につけての結果を図 5 亿示 す. 図より吸着前の試料に認められた II-CaSO 4 が吸着 後 $\mathrm{CaCO}_{8}$ に変化していること及び二ウラン酸カルシウ ム (calcium diuranate, $\mathrm{CaU}_{2} \mathrm{O}_{7},{ }^{11), 12)}$, ASTM card 8-405)の 3 本の小さい回折ピークが現れていることが 分る.

\section{$3.9 \mathrm{C}_{5} \mathrm{~A}_{3}$ 及び $\mathrm{C}_{3} \mathrm{~A}$ 粉末のウラン吸着}

合成した $\mathrm{C}_{5} \mathrm{~A}_{3}$ 粉末は $2 \theta=30.1$ の回折ピークが最も 大きかった．このピークは強度 100 のピークではない が, $\mathrm{SO}_{3}$ 成分を含む $1000^{\circ} \mathrm{C}$ 焼成試料にもこの $2 \theta$ 位置 に $\mathrm{C}_{5} \mathrm{~A}_{3}$ の大きいピークが現れる. $\mathrm{C}_{5} \mathrm{~A}_{3}$ の他のピー クも強度が文献 ${ }^{100}$ に一致せず, $\mathrm{C}_{3} \mathrm{~A}$ 結晶と思われるピー クも認められた.これに対して $\mathrm{C}_{3} \mathrm{~A}$ 粉末の回折ピーク の位置と強度は文献の值 ${ }^{10)}$ とほぼ一致した。これらの粉 末を吸着液に浸漬し容器を振とうすると粒子強度が小さ レためけずれも吸着液が白濁した。遠心分離後こ机らの 吸着率を求めたところ，いずれも $100 \%$ に近い值をとる が $\mathrm{C}_{3} \mathrm{~A}$ 粉末の方が $\mathrm{C}_{5} \mathrm{~A}_{3}$ 粉末より吸着率が大きかった。 吸着率測定後の $\mathrm{C}_{3} \mathrm{~A}$ 粉末の $\mathrm{X}$ 線回折を行ったところ, $\mathrm{C}_{3} \mathrm{~A}$ 結晶はほとんど $\mathrm{CaCO}_{3}$ に変化しているが, $\mathrm{CaU}_{2} \mathrm{O}_{7}$ 結晶の 3 本の小さいピーク.も認められた. $100 \mathrm{ppm}$ の吸 着液に短時間浸漬してウラン化合物を検出できた試料の

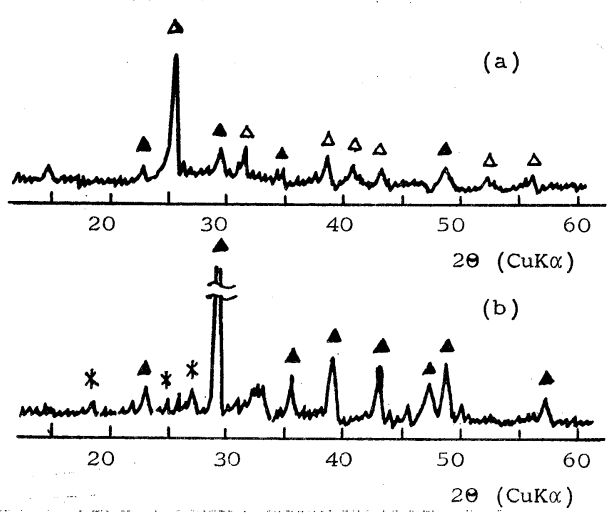

Fig. 5. X-ray powder diffraction patterns of pressed surfaces of calcined materials having $2.9 \mathrm{CaO} \cdot \mathrm{Al}_{2} \mathrm{O}_{3} \cdot 1.4 \mathrm{SO}_{3}$ composition before and after immersion into solutions containing 2000 ppm of $\mathrm{U}(\mathrm{VI})$ ions.

(a) : Materials calcined at $600^{\circ} \mathrm{C}$ for one hour, before immersion.

(b) : Materials calcined at $600^{\circ} \mathrm{C}$ for one hour, after immersion.

$\triangle: \mathrm{II}-\mathrm{CaSO}_{4}, \mathbf{\Delta}: \mathrm{CaCO}_{3}$ (calcite), $*: \mathrm{CaU}_{2} \mathrm{O}_{7}$ 
例として吸着前後のX線回折図を図 6 (a)，（b) に示す. 図 6 (c) अ純水に 2 時間浸漬後の同心゙試料の回折図で, 加水分解の結果 2 種の水和物が生成していることを示 す. 図 6 (b) と（c) に見られる $2 \theta=11^{\circ}$ 付近の大きい ピークは水和物結晶の回折ピークと考えられるが明らか ではない. $\mathrm{C}_{5} \mathrm{~A}_{3}$ 及び $\mathrm{C}_{3} \mathrm{~A}$ 粉末を純水に浸漬すると液の $\mathrm{pH}$ は約 20 分後にそれぞれ 10〜11 及び 12 となり, 以後はいずれも $\mathrm{pH}$ の值に変化がなかった，吸着液の $\mathrm{pH}$ もこれらの試料の浸漬により $\mathrm{C}_{5} \mathrm{~A}_{3}$ では $9 \sim 10$, $\mathrm{C}_{3} \mathrm{~A}$ では 11 となり, この值は 2 時間後も変らないこと が分った. $\mathrm{C}_{3} \mathrm{~A}$ の場合の結果を図 7 に示す.

\subsection{0 市販セメントの吸脱着}

ポルトランドセメント及びアルミナセメント微粉末の ウラン吸着率はいずれも100\%（ただし遠心分離したと きの值) であった。これらの微粉末に水を $70 \%$ 加えて 凝結させ， 3 日間放置後粉碎し，所定の粒度の試料を用 いて吸着試験を行ったところ，残留液は濁らず，吸着率 はいずれも約 90\%，脱着率は 70〜80\% であった。な

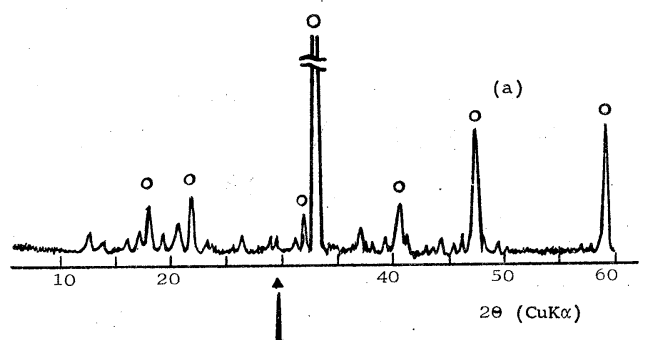

(b)

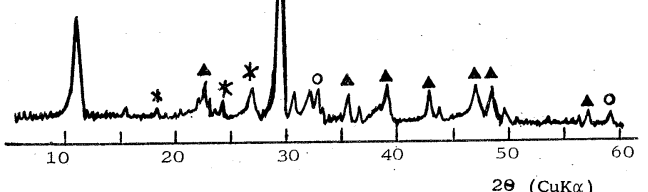

$2 \theta(\mathrm{CuK} \alpha)$

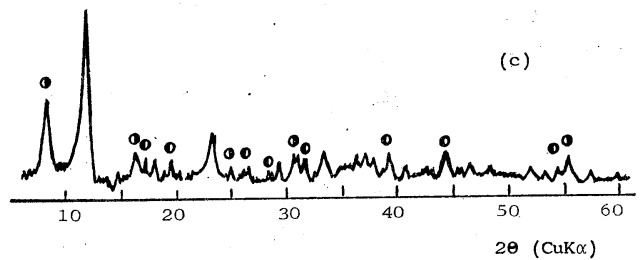

Fig. 6. X-ray diffraction patterns of calcined powders of $3 \mathrm{CaO} \cdot \mathrm{Al}_{2} \mathrm{O}_{3}$ composition before and after immersion into solution containing $100 \mathrm{ppm}$ of $U(V I)$ ions or pure water. The samples subjected to $\mathrm{pH}$ measurement were used after dried.

(a) : $3 \mathrm{CaO} \cdot \mathrm{Al}_{2} \mathrm{O}_{3}$ powders calcined at $1400^{\circ} \mathrm{C}$ for 3 hours, before immersion.

(b) : $3 \mathrm{CaO} \cdot \mathrm{Al}_{2} \mathrm{O}_{3}$ powders after immersion into $\mathrm{U}(\mathrm{VI})$ containing solution.

(c) : $3 \mathrm{CaO} \cdot \mathrm{Al}_{2} \mathrm{O}_{3}$ powders after immersion into pure water.

O : $3 \mathrm{CaO} \cdot \mathrm{Al}_{2} \mathrm{O}_{3}, \boldsymbol{\Delta}: \mathrm{CaCO}_{3}$ (calcite), * : $\mathrm{CaU}_{2} \mathrm{O}_{7}$,

- : $3 \mathrm{CaO} \cdot \mathrm{Al}_{2} \mathrm{O}_{3} \cdot 6 \mathrm{H}_{2} \mathrm{O}, 2 \mathrm{CaO} \cdot \mathrm{Al}_{2} \mathrm{O}_{3} \cdot 3 \mathrm{H}_{2} \mathrm{O}$.

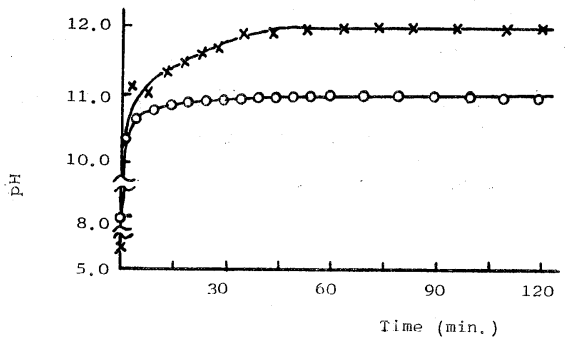

Fig. 7. Changes in $\mathrm{pH}$ of pure water and $\mathrm{U}(\mathrm{VI})$ containing solution caused by immersion of calcined powders of $3 \mathrm{CaO} \cdot \mathrm{Al}_{2} \mathrm{O}_{3}$ composition. $-x-: 0.100^{\circ} \mathrm{g}$ of powders calcined at $1400^{\circ} \mathrm{C}$ was immersed in $50 \mathrm{ml}$ of pure water.

$-0-: 0.100 \mathrm{~g}$ of powders calcined at $1400^{\circ} \mathrm{C}$ was immersed in $50 \mathrm{ml}$ of solution containing $100 \mathrm{ppm}$ of $\mathrm{U}(\mathrm{VI})$ ions.

拉残留液の $\mathrm{pH}$ 江 いずれの場合も 12 以上の值を示 した.

3.11 吸着液と 消石灰液の 反応

本研究で調製し た試料のウラン吸 着機構を明らかに するため以下の実 験を行った。すな わち $\mathrm{pH} 8.0$ のウ ラン吸着液 $50 \mathrm{ml}$
Fig. 8. Precipitation rate of $\mathrm{U}(\mathrm{VI})$ ions in solution vs. $\mathrm{pH}$ value. $\mathrm{Ca}(\mathrm{OH})_{2}$ solution was added to the solution containing $100 \mathrm{ppm}$ of U(VI) ions at rate of $1 \mathrm{ml} / \mathrm{min}$.

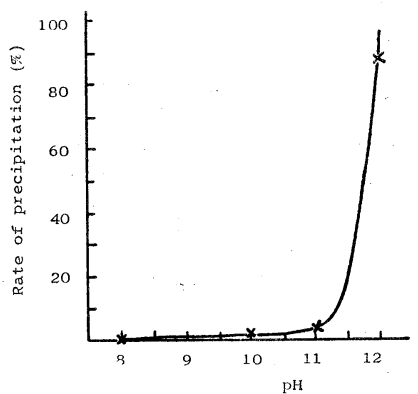

に透明な飽和消石灰液の $20 \mathrm{ml}$ を $1 \mathrm{ml} /$ 分の速度で加え て液の $\mathrm{pH}$ を変え, 生成する沈殿の種類, ウラン沈殿 率などを調べた。その結果まず飽和消石灰水を約 $6 \mathrm{ml}$ 加え, 液の $\mathrm{pH}$ が 10 となると白色沈殿が生成したが, これは $\mathrm{CaCO}_{3}$ であることが分った.引き続き消石灰液を 添加すると液の $\mathrm{pH}$ が急に大きくなった。 これは次の 式で示すように, $\mathrm{Ca}(\mathrm{OH})_{2}$ のうち $\mathrm{Ca}^{2+}$ が $\mathrm{CaCO}_{3}$ の

$$
\begin{aligned}
3 \mathrm{Ca}(\mathrm{OH})_{2}+ & {\left[\mathrm{UO}_{2}\left(\mathrm{CO}_{3}\right)_{3}\right]^{4-} } \\
& \rightarrow 3 \mathrm{CaCO}_{3}+\mathrm{UO}_{2}(\mathrm{OH})_{3}{ }^{-}+3 \mathrm{OH}^{-}
\end{aligned}
$$

生成に費され， $\mathrm{OH}^{-}$が一時的に多くなるためであろう。 $\mathrm{UO}_{2}(\mathrm{OH})_{2} \mathrm{H}_{2} \mathrm{O}$ の沈殿も考えられるが $\mathrm{X}$ 線回折で検出で きなかった. 液の $\mathrm{pH}$ が 11 12 になると黄色の沈殿が 生成したが，これは前記の $\mathrm{CaU}_{2} \mathrm{O}_{7}$ 結晶である。 これ を式で書くと次の (2) 式のようになる.

$$
\begin{aligned}
\mathrm{Ca}(\mathrm{OH})_{2} & +2 \mathrm{UO}_{2}(\mathrm{OH})_{3}{ }^{-} \\
\rightarrow & \mathrm{CaU}_{2} \mathrm{O}_{7}+2 \mathrm{OH}^{-}+3 \mathrm{H}_{2} \mathrm{O}
\end{aligned}
$$

液の $\mathrm{pH}$ が 10,11 及び 12 になったところで消石灰液 
心分離にかけ，液中のウラン量を分析し，その分析值か らウランの沈殿率を計算してその值と $\mathrm{pH}$ の関係を求め の添加を中止して液を遠た（ただし液量が時間ととも に増すためウラン量の分析値に補正を加えた).この結果 を図 8 に示す. 図よりウランの沈殿生成が顕著になるの は液の $\mathrm{pH}$ が 11 以上であることが分る.

\section{4. 考察}

\section{1 構成成分亡試料仮焼温度の関係}

本研究では $\mathrm{CaO}$ や $\mathrm{Al}_{2} \mathrm{O}_{3}$ を主成分とする吸着材料 を湿式で調製する場合に, 適量の $\mathrm{SO}_{4}{ }^{2-}$ がこれらの成 分と結合してまず安定な複塩を生成する．したがって試 料が均一となり，比較的低温の仮焼で所望の材料が得ら れるという利点がある.すなわち出発原料として用いた $\mathrm{Al}_{2}\left(\mathrm{SO}_{4}\right)_{3}$ 中の $\mathrm{SO}_{3}$ 成分は, 焼成前の沈殿物中に主に エットリンジャイト (ettringite, $6 \mathrm{CaO} \cdot \mathrm{Al}_{2} \mathrm{O}_{3} \cdot 3 \mathrm{SO}_{3}$. $32 \mathrm{H}_{2} \mathrm{O}$, 以下 $\mathrm{E}$ 結晶と略す) として残留する. Jones や D'Ans らは $\mathrm{CaO}-\mathrm{Al}_{2} \mathrm{O}_{3}-\mathrm{CaSO}_{4}-\mathrm{H}_{2} \mathrm{O}$ の研究で $25^{\circ} \mathrm{C}$ における $\mathrm{E}$ 結晶の安定領域がかなり広いこと，しかし $\mathrm{Ca}(\mathrm{OH})_{2}$ 過剩のときは $\mathrm{E}$ 結晶の溶解度が増しその生成 量が減少することを示した ${ }^{13), 14)}$. 本研究でも $\mathrm{Al}_{2}\left(\mathrm{SO}_{4}\right)_{3}$ の半量を $\mathrm{AlCl}_{3}$ で置換したにもかかわらず $\mathrm{E}$ 結晶のみ 生成し, $\mathrm{Al}_{2}\left(\mathrm{SO}_{4}\right)_{3}$ を用いず $\mathrm{AlCl}_{3}$ のみを用いた場合 に生成する $\mathrm{CaCl}_{2}$ を含む結晶は生成しなかった (3.1節). これは同じ複塩でも $\mathrm{SO}_{4}$ を含む結晶の方が $\mathrm{Cl}^{2}$ を含む 結晶より複塩を生成する傾向が大きいためと考えられ る。しかし原料混合液の量が増すと， E 結晶と共存する $\mathrm{CaSO}_{4} \cdot 2 \mathrm{H}_{2} \mathrm{O}$ が溶解するのみならず $\mathrm{E}$ 結晶そのものの 生成量も減少した．また液量を少なくすると沈殿物中に $\mathrm{Ca}$ や $\mathrm{SO}_{4}$ が増加して焼成試料中に II- $\mathrm{CaSO}_{4}$ が多くな り，試料を構成する粒子強度がかえって小さくなるの で，適量の $\mathrm{SO}_{4}$ を沈殿物中に残留させることが望まし いと考えられる。更に沈殿物が $\mathrm{E}$ 結晶のみから構成され るならば， $500^{\circ} \mathrm{C}$ 以上 $1000^{\circ} \mathrm{C}$ まで加熱したときに生 成する結晶は，II-CaSO 4 のほかは $3 \mathrm{CaO} \cdot \mathrm{Al}_{2} \mathrm{O}_{3}$ とな るはずである。しかし焼成試料中に見いだされる $\mathrm{Ca}$-ア ルミネートの結晶は主に $5 \mathrm{CaO} \cdot 3 \mathrm{Al}_{2} \mathrm{O}_{3}$ である(図 1 ). これは焼成前の試料が $\mathrm{Al}_{2} \mathrm{O}_{3}$ 成分過剩すなわち沈殿物 中にエットリンジャイトのほかに少量のアルミナゲルが 存在することを示すと考えられる.

$\mathrm{X}$ 線回折で $\mathrm{E}$ 結晶が認められる試料を 加熱すると， $100^{\circ} \mathrm{C}$ までにE結晶が分解し，いったん回折ピークは消 失するが, $500^{\circ} \mathrm{C}$ になると少量の $\mathrm{CaCO}_{3}$ (calcite) と II$\mathrm{CaSO}_{4}$ が生成する (図 1 参照). 表 2 の試料の加熱減量 は $\mathrm{H}_{2} \mathrm{O}+\mathrm{CO}_{2}$ で, このうち $\mathrm{H}_{2} \mathrm{O}$ は主にアルミナゲル の残留水分（アルミナゲルのみの実験では約 7\%) であ るから, $\mathrm{CO}_{2}$ したがって $\mathrm{CaCO}_{3}$ の量が求まる。この量 は試料 C については約 $10 \%$ である. $500^{\circ} \mathrm{C}$ 焼成試料
では, II- $\mathrm{CaSO}_{4}$ は $\mathrm{CaCO}_{3}$ より少ない（図 $1 \mathrm{X}$ 線回折 図) が， $600^{\circ} \mathrm{C}$ 焼成試料ではこの関係が逆になり，固体 反応が進行したことを示している， $\mathrm{C}_{5} \mathrm{~A}_{3}$ 及び $\mathrm{C}_{3} \mathrm{~A}$ 結 晶は II- $\mathrm{CaSO}_{4}$ より遅れて成長し，これらの結晶が増大 し始めるのは $1000^{\circ} \mathrm{C}$ 近くである.したがって $500^{\circ} や$ $600^{\circ} \mathrm{C}$ で焼成した試料の大部分は, $\mathrm{II}-\mathrm{CaSO}_{4}$ や上記 $\mathrm{Ca}$ アルミネートの著しい結晶化が起こる前段階の活性に 富んだ非晶質成分であると考えられる.なお使用した Ca $(\mathrm{OH})_{2}$ の中の少量の大きい粒子はそのまま $\mathrm{E}$ 結晶中に 残存し $500^{\circ} \mathrm{C}$ では $\mathrm{CaO}$ となる. 図 1 の $\mathrm{X}$ 線回折図で 認められる $\mathrm{CaCO}_{3}$ は室温で生成したものもあるが, 大 部分は焼成中 $\mathrm{CaO}$ の表面の炭酸塩化により生成したの であろう。

\section{2 ウラン吸着液の吸収スペクトル}

$\mathrm{Na}_{2} \mathrm{CO}_{3}$ 溶液中に含まれる $\left[\mathrm{UO}_{2}\left(\mathrm{CO}_{3}\right)_{8}\right]^{4-}$ イオンの 紫外部吸収スペクトルは, 古くは Blake ら ${ }^{15)}$ にっって,

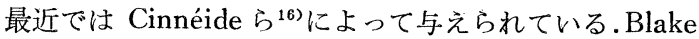
らは $0.035 \mathrm{M} \mathrm{U}(\mathrm{VI}), \mathrm{CO}_{3} / \mathrm{U}=5$ の液について 400〜 $470 \mathrm{~nm}$ の間に四つの吸収があることを示した.Cinnéide らは $\left[\mathrm{UO}_{2}{ }^{2+}\right]=0.003 \mathrm{M},\left[\mathrm{Na}_{2} \mathrm{CO}_{3}\right]=0.1 \mathrm{M}$ の液につ いてほぼ同じ吸収曲線を示している。著者らが調製した ウラン吸着液は濃度が $0.0004 \mathrm{M} \mathrm{U}(\mathrm{VI})$ でかなり小さ いが，前二者の場合とほぼ同じ強度比をもつ四つの吸収 曲線が認められた（図 $2(\mathrm{~d})$ ). ただ前二者に比し吸収ピ 一クの位置が全体に低波長にずれており，この原因は明 らかでない。しかし吸収ピークの波長から波数を計算し 各波数の差を求めると，波数は増大するのに波数差はほ ぼ同じで，これらの吸収が別々の化学種によるものでな いことが分る。したがって U(VI) 濃度は小さいが液中 $\mathrm{U}(\mathrm{VI})$ はほとんど $\left[\mathrm{UO}_{2}\left(\mathrm{CO}_{3}\right)_{3}\right]^{4-}$ の形で含まれると 考えられる.しかし $\mathrm{pH} 8.0$ の吸着液の吸収は $\mathrm{pH} 10.5$ のウラン含有液のそれと形状は同じであるが，上記の吸 収の強度が小さい。これは次の式で示すように $\left[\mathrm{UO}_{2}\right.$ $\left.\left(\mathrm{CO}_{3}\right)_{3}\right]^{4-}$ の一部が少量の $\mathrm{UO}_{2}{ }^{2+}$ に変化したためと考 えられる。

$$
\begin{aligned}
\mathrm{Na}_{4} \mathrm{UO}_{2}\left(\mathrm{CO}_{3}\right)_{3}+3 \mathrm{HCl} & \\
\quad & \rightleftarrows \mathrm{UO}_{2}{ }^{2+}+3 \mathrm{NaHCO}_{3}+\mathrm{NaCl}+2 \mathrm{Cl}^{-}
\end{aligned}
$$

図 3 の赤外吸収スペクトル曲線でも, $\mathrm{pH} 8.0$ の液は, 1370 及び $1500 \mathrm{~cm}^{-1}$ の吸収（いずれも錯イオン中の $\mathrm{CO}_{3}{ }^{2-}$ によるもの) が $\mathrm{pH} 10.5$ の液のそれより小さい ことが分る. $\left[\mathrm{UO}_{2}\left(\mathrm{CO}_{3}\right)_{3}\right]^{4-}$ を吸着した試料でもこの二 つの吸収が吸着前より大きくなること福から，上記位置 の赤外吸収の変化は $\left[\mathrm{UO}_{2}\left(\mathrm{CO}_{3}\right)_{3}\right]^{4-}$ の変化を示すもの であろう.

\section{3 ウラン吸着率と試料の加水分解の関係}

カルシウム化合物のうち水溶液中の $\mathrm{U}(\mathrm{VI})$ を吸着す るのは $\mathrm{Ca}(\mathrm{OH})_{2}$ のみでその吸着率は大きい（表 3 ). 試料 $\mathrm{A}, \mathrm{B}$ 及び $\mathrm{C}$ のいずれにも $\mathrm{X}$ 線回折で $\mathrm{Ca}(\mathrm{OH})_{2}$ 
が認められないが，これらの試料粉末を純水に浸漬する と液の $\mathrm{pH}$ が大きくなる（図 4）のでこれらの試料中の ある成分が加水分解して $\mathrm{Ca}(\mathrm{OH})_{2}$ を生成すると考えら れる。 また試料の表面は II- $\mathrm{CaSO}_{4}$ や $\mathrm{CaCO}_{3}$ が生成し ていても内部はまだ末反応の $\mathrm{CaO}$ をつ粒子が残存し， それが $\mathrm{Ca}(\mathrm{OH})_{2}$ として外部へ溶出することが考えられ る.

次に加水分解して $\mathrm{Ca}(\mathrm{OH})_{2}$ を生成しやすい試料ほど ウラン吸着率が大きいことを $\mathrm{C}_{3} \mathrm{~A}$ 結晶粉末の場合を例 として説明する.この粉末を吸着試料として用いると， 2 時間吸着液に浸漬するだけで試料 $\mathrm{A}, \mathrm{B}$ 及び Cに生成 したのと同じウラン化合物が生成する（図6）。これは $\mathrm{C}_{3} \mathrm{~A}$ 粉末では試料の一部でなく全体が次の一連の式で 示すように加水分解し, 多量の $\mathrm{Ca}(\mathrm{OH})_{2}$ を生成するた めと考えられる(図 7 ).

$$
\begin{aligned}
\mathrm{Ca}_{3} \mathrm{Al}_{2} \mathrm{O}_{6}+\mathrm{H}_{2} \mathrm{O} & \rightarrow \mathrm{Ca}_{2} \mathrm{Al}_{2} \mathrm{O}_{5}+\mathrm{Ca}(\mathrm{OH})_{2} \\
\mathrm{Ca}_{2} \mathrm{Al}_{2} \mathrm{O}_{5}+\mathrm{H}_{2} \mathrm{O} & \rightarrow \mathrm{CaAl} \mathrm{O}_{4}+\mathrm{Ca}(\mathrm{OH})_{2} \\
\mathrm{CaAl}_{2} \mathrm{O}_{4}+3 \mathrm{H}_{2} \mathrm{O} & \rightarrow 2 \mathrm{Al}(\mathrm{OH})_{3}+\mathrm{CaO} \\
\mathrm{CaO}+\mathrm{H}_{2} \mathrm{O} & \rightarrow \mathrm{Ca}(\mathrm{OH})_{2}
\end{aligned}
$$

$\mathrm{C}_{3} \mathrm{~A}$ 結晶はポルトランドセメント及びアルミナセメ ントを構成する結晶で，これらのセメント粉末及び水和 物粒子がウランを吸着しやすい（3.10 節）のも上 記加 水分解の結果と考えられる ${ }^{18)}$.

$1000^{\circ} \mathrm{C}$ で焼成した試料 $\mathrm{A}, \mathrm{B}$ 及び $\mathrm{C}$ を構成する結 晶のうち加水分解するのは $\mathrm{C}_{5} \mathrm{~A}_{3}$ と $\mathrm{C}_{3} \mathrm{~A}$ であるが，多 量含まれる前者は後者ほどには加水分解しない (3.9節). $500^{\circ} \mathrm{C} 600^{\circ} \mathrm{C}$ の低温で焼成した試料でも,これらの結 晶は多分まだ非晶質でその構造は結晶と似ているが $\mathrm{C}_{3} \mathrm{~A}$ ほどに加水分解するとは思えない，したがってこの点で は両試料に差異はないが，低温焼成試料が高温焼成試料 よりウラン吸着率が大きいのは，試料中未反応の $\mathrm{CaO}$ も含まれ，大部分が表面活性の大きい構造をもつためと 考えられる.

\section{4 ウラン吸脱着機構}

$\mathrm{X}$ 線回折の結果（図 5, 図 6) はウラン吸着液に浸漬 した試料表面では，少量のウラン化合物が生成するほ か, 浸漬する前の $\mathrm{II}-\mathrm{CaSO}_{4}$ または $\mathrm{C}_{3} \mathrm{~A}$ が浸漬後ほとん ど $\mathrm{CaCO}_{3}$ (calcite) に変化し，また新しく少量の $\mathrm{CaCO}_{3}$ が生成するなどの変化が起こっている．ウラン吸着液に 飽和石灰水を加えた実験 (3.11 節) でも液の $\mathrm{pH}$ が 10 付 近で $\mathrm{CaCO}_{3}$ が生成した後 $\mathrm{pH} 11$ を越えて $\mathrm{CaU}_{2} \mathrm{O}_{7}$ が 急速に沈殿した. 先にこの過程を二つに分けて考えた が，これらを一つの式で示すと次の式のようになる.

$$
\begin{aligned}
7 \mathrm{Ca}(\mathrm{OH})_{2} & +2 \mathrm{Na}_{4} \mathrm{UO}_{2}\left(\mathrm{CO}_{3}\right)_{3} \\
& \rightarrow 6 \mathrm{CaCO}_{3}+\mathrm{CaU}_{2} \mathrm{O}_{7}+8 \mathrm{NaOH}+3 \mathrm{H}_{2} \mathrm{O}
\end{aligned}
$$

ただしウラン吸着液中に少量含まれる $\left[\mathrm{UO}_{2}\left(\mathrm{CO}_{3}\right)_{3}\right]^{4-}$ 以外の他のイオンは省略した。上記の式は前記混合液か ら $\mathrm{CaCO}_{3}$ と $\mathrm{CaU}_{2} \mathrm{O}_{7}$ 結晶が沈殿する反応を示してい
る.これを参考として試料 $\mathrm{A}, \mathrm{B}$ 及びCをウラン吸着液 に浸漬したときのウラン吸着機構を以下に記す。

まずウラン吸着液は $100 \mathrm{ppm}$ のウラン含有液に炭酸 ソーダを加え, 更に塩酸で $\mathrm{pH}$ を 8.0 に調節したので, 吸着液の構成は次の（1）式の右辺ようになる.

$$
\begin{aligned}
\mathrm{UO}_{2}{ }^{2+} & +2 \mathrm{Cl}^{-}+5 \mathrm{Na}_{2} \mathrm{CO}_{3}+2 \mathrm{HCl} \\
& \rightarrow 4 \mathrm{NaCl}+\mathrm{Na}_{4} \mathrm{UO}_{2}\left(\mathrm{CO}_{3}\right)_{3}+2 \mathrm{NaHCO}_{3}
\end{aligned}
$$

弱アルカリ性の吸着液中でウランはほとんど安定な $\left[\mathrm{UO}_{2}\left(\mathrm{CO}_{3}\right)_{3}\right]^{4-}$ の形で含まれていることはすでに述べた (3.5節 と 4.2 節).一方吸着試料は少量のII- $\mathrm{CaSO}_{4}$ を骨 格とし,加水分解して $\mathrm{Ca}(\mathrm{OH})_{2}$ を生成しやすい大部分の マトリックスよりなる.したがってこの構成を II- $\mathrm{CaSO}_{4}$ と $\mathrm{Ca}(\mathrm{OH})_{2}$ の混合物と見なすと,

$$
\begin{aligned}
& \frac{4 \mathrm{CaSO}_{4}+8 \mathrm{Ca}(\mathrm{OH})_{2}}{\text { 吸着 }} \\
& +\frac{6 \mathrm{NaCl}+2 \mathrm{Na}_{4} \mathrm{UO}_{2}\left(\mathrm{CO}_{3}\right)_{3}+2 \mathrm{NaHCO}_{3}}{\text { 吸 着 液 }} \\
& \rightarrow \frac{8 \mathrm{CaCO}_{3}+\mathrm{CaU}_{2} \mathrm{O}_{7}}{\text { 吸 着 剂 }} \\
& +\frac{4 \mathrm{Na}_{2} \mathrm{SO}_{4}+3 \mathrm{CaCl}_{2}+8 \mathrm{NaOH}+5 \mathrm{H}_{2} \mathrm{O}}{\text { 吸 着 液 }}
\end{aligned}
$$

のように表わせる。この式の内容を図 5，6 及び (3.11 節) の実験結果に基づき説明すると，1）試料に接してい る吸着液中の $\left[\mathrm{UO}_{2}\left(\mathrm{CO}_{3}\right)_{3}\right]^{4-}$ は, 加水分解のため試料 から生成した $\mathrm{Ca}(\mathrm{OH})_{2}$ によって次第に分解し, $\mathrm{pH} 10$ で $\mathrm{CaCO}_{3}$ が生成する，2)この反応の際，遊離する過剩の $\mathrm{CO}_{3}{ }^{2-}$ によって試料表面の II-CaSO${ }_{4}$ が $\mathrm{CaCO}_{3}$ に変化 する. 3) $\mathrm{CaCO}_{3}$ の生成に伴って試料表面に接している 液の $\mathrm{pH}$ が上昇するため, 高アルカリで安定な $\mathrm{CaU}_{2} \mathrm{O}_{7}$ 結晶が試料表面に生成するものと考えられる.

一方，脱着機構は試料表面に生成した $\mathrm{CaCO}_{3}$ が脱着 液によって影響を受けないのでこれを除いて考えると，

$$
\begin{aligned}
& \mathrm{CaU}_{2} \mathrm{O}_{7}+8 \mathrm{NaHCO}_{3} \\
& \stackrel{60^{\circ} \mathrm{C}}{\longrightarrow} 2 \mathrm{Na}_{4} \mathrm{UO}_{2}\left(\mathrm{CO}_{3}\right)_{3}+\mathrm{CaCO}_{3}+\mathrm{CO}_{2}+4 \mathrm{H}_{2} \mathrm{O}
\end{aligned}
$$

のように書ける. 吸着したウランの脱着がかなり容易に 行われるのは，(3) 式に示すように U(VI) が弱アルカ リ液で安定な $\left[\mathrm{UO}_{2}\left(\mathrm{CO}_{3}\right)_{3}\right]^{4-}$ にもどりやすいためと考 えられる。

なお本研究で調製した焼成試料をウラン吸着液に浸漬 すると，前記のように試料の一部が $\mathrm{Ca}(\mathrm{OH})_{2}$ に変化 し，これがウラン化合物の生成に導く。したがって本試 料のウラン捕集速度は大きいが, 表 3 に示したように吸 脱着の繰り返し使用は困難である．原料コストは低いの で 1 回きりの使用でもよいが，出発物質の沈殿物の微粉 末をプレス成形し，これを焼成後所定の粒度にして使用 したり，また脱着後の試料を再焼成して使用するなどの 方法をとれば，繰り返し使用の方向で改善の余地はある ものと考えられる。 


\section{5. 総 括}

硫酸アルミニウム $\mathrm{Al}_{2}\left(\mathrm{SO}_{4}\right)_{8} \cdot 18 \mathrm{H}_{2} \mathrm{O}(2.06 \mathrm{~g} / 100 \mathrm{ml})$, 塩化アルミニウム $\mathrm{AlCl}_{3} \cdot 6 \mathrm{H}_{2} \mathrm{O}(1.48 \mathrm{~g} / 100 \mathrm{ml})$ 水溶液 及び消石灰乳液 $(0.94 \mathrm{~g} / 50 \mathrm{ml})$ を種々の容積比に混合 し, 生成した沈殿物を沪過した. 漏斗上に残った白色の ケーキを構成する結晶は主にエットリンジャイト（ettringite, $\left.6 \mathrm{CaO} \cdot \mathrm{Al}_{2} \mathrm{O}_{3} \cdot 3 \mathrm{SO}_{3} \cdot 32 \mathrm{H}_{2} \mathrm{O}\right)$ である. 次にこの ケーキを $300^{\circ} \sim 1000^{\circ} \mathrm{C}$ の種々の温度に 30 分焼成し, 粉砕して 80 200 メッシュの範囲の粒度をもつ試料粉末 を調製した。

水溶液に溶解しているウランに対する試料粉末の吸着 能は, ウランの $100 \mathrm{ppm}$ を主に $\left[\mathrm{UO}_{2}\left(\mathrm{CO}_{3}\right)_{3}\right]^{4-}$ の形 で含む水溶液の $50 \mathrm{ml}$ 中にそれらの粉末の $0.100 \mathrm{~g}$ を 2 時間浸漬することにより決定した. 試料粉末が吸着し たウランの量は, 吸着後の溶液中に残ったウランを TBP 溶液で抽出し, 吸光度法によって決定した。 得ら れた結果は以下のように要約できる。

1) 調製した試料の中で酸化物組成が $2.9 \mathrm{CaO} \cdot \mathrm{Al}_{2} \mathrm{O}_{3}$ $\cdot 1.4 \mathrm{SO}_{3}$. 及び $2.5 \mathrm{CaO} \cdot \mathrm{Al}_{2} \mathrm{O}_{3} \cdot 1.2 \mathrm{SO}_{3}$ の，いずれも $500^{\circ} \mathrm{C}$ 及び $600^{\circ} \mathrm{C}$ で焼成した試料がウランに対し高い吸 着能を示した. 溶液中に始めに溶解しているウランの量 に対する試料が吸着したウランの量の割合は $80 \sim 100 \%$ であった。この值は従来, 海水中に存在する微量のウラ ンに対し高い吸着能をもつことが知られている含水酸化 チタン粉末の值より大きかった.

2) 上記粉末中には, $\mathrm{X}$ 線回折により少量の II- $\mathrm{CaSO}_{4}$ と $\mathrm{CaCO}_{3}$ (calcite) 結晶が含まれることが分った. しか し試料粉末の大部分は非晶質状態のエットリンジャイト 結晶の脱水生成物であると考えられる. 粉末の各粒子は 硬くて, 水中及びアルカリ溶液中で長時間その形を保持 した.

3) ウラン含有液中に浸漬した試料粉末の表面には, 少量の二ウラン酸カルシウム塩 $\left(\mathrm{CaU}_{2} \mathrm{O}_{7}\right)$ の結晶が, 多 量のカルサイト $\left(\mathrm{CaCO}_{3}\right)$ の結晶とほとんど同時に生成
して黄色い薄層を形成していることが分った.この層は 多分, 試料粉末から溶出した $\mathrm{Ca}^{2+}$ が溶液中に存在する $\left[\mathrm{UO}_{2}\left(\mathrm{CO}_{3}\right)_{3}\right]^{4-}$ と反応して生成するのであろう.

4) 試料粉末の表面に生成した $\mathrm{CaU}_{2} \mathrm{O}_{7}$ 結晶は $60^{\circ} \mathrm{C}$ に保った $5 \% \mathrm{NaHCO}_{3}$ 溶液の $50 \mathrm{ml}$ 中に 1 時間浸漬 することによって脱着させることができた. その脱着率 は 70 80 wt\% である.

謝辞 本研究に際し御指導賜わりました京都大学化学研 究所 田代 仁教授及び御討論いただきました松井正和助教授 上小久保 正助教授に厚く拉礼申し.トビます。

\section{文献}

1) 筒井天尊, 他, KURRI-IR-81, 1-13 (1970) ; KURRITR-91, 1-8 (1971).

2) 简井天尊, 他, KURRI-IR-124, 1-19 (1974); KURRITR-186, 1-18 (1979).

3) S. Ahrland, et al., Acta Chem. Scand., 14, 1077 (1960); C.B. Amphlett, "Inorganic Ion Exchangers", Elsevier, (1964) p. 89.

4）罙崎秀甫, 化学教育, 27, 41 (1979); 菅坡和彦, $M O L$, (7) $1-7$ (1980).

5) 尾方 昇, 日本海水学会誌, 30, 3 (1976).

6) 牧 俊夫, H本化学会誌, [7] 945 (1978).

7) L.G. Sillen, "Stability Constants of Metal-Ion Complexes", The Chem. Soc., London; I (1964) p. 138.

8) B. Paige et al., Anal. Chem., 29, 1029 (1957).

9) R. Bogue, "The Chemistry of Portland Cement", Reinhold (1955) p. 582 , p. 575.

10) R. Bogue, ibid., p. 334 , p. 740.

11) M.E. Mrose, Am. Mineral., 38, 1159 (1953).

12) E. Cordfunke and B. Loopstra, J. Inorg. Nucl. Chem., 29, 51 (1967).

13) F. Jones, Trans. Farad. Soc., 35, 1484 (1935).

14) J. D'Ans and H. Eick, Zement-Kalk-Gips, 6, 302 (1953).

15) C. Blake et al., J. Am. Chem. Soc., 78, 5978(1956).

16) S. Cinnéide et al., J. Inorg. Nucl. Chem., 37, 1013 (1975).

17) T. Maki, Inst. Chem. Res. Kyoto Univ., 59, to be published.

18) J. Birchall et al., Proc. Roy. Soc., A 360, 445 (1978). 